\title{
Needs Analysis of Teaching Materials Poetry Appreciation for Kuningan University Students
}

\author{
Hidayat Arip ${ }^{1}$, Boeriswati $\mathrm{E}^{2}$, Rohman $\mathrm{S}^{\mathbf{3}}$ \\ Universitas Negeri Jakarta, Indonesia \\ \{ariphidayat7317167633@mhs.unj.ac.id\}
}

\begin{abstract}
This study aims to determine the need for teaching materials in the poetry appreciation course in Kuningan University. The results of the preliminary study stated that the value of the poetry appreciation course was below the average value of the appreciation of fiction and drama. This is because the poetry appreciation course is a difficult subject. The reasons stated why poetry appreciation is difficult include the character of the language of poetry which is relatively different from prose, the process and stages of poetry appreciation which are complex, and teaching materials that are not in accordance with learning outcomes. The inadequacy of teaching materials is caused by the limited number of teaching materials for poetry appreciation. Puspita, Andayani, Waluyo, and Rohmadi also expressed the teaching materials for poetry appreciation (2017: 622-623). The results of their research stated that the results of the survey of poetry appreciation textbooks used by universities in Central Java were still minimal. The books used in six universities in Central Java are the Pengkajian dan Apresiasi Puisi, Pengkajian Puisi, Berkenalan dengan Puisi, Stilistika, dan Wacana Musikalisasi. Based on this background, the focus in this study is to analyze the needs of poetry appreciation teaching materials (needs, lacks, want) for students at the Kuningan University. The samples in this study were students and lecturers at the Indonesian Language and Literature Study Program, Kuningan University. The research method used is descriptive analysis. The data collection technique used was interviews. Based on the results of the interview, it can be concluded that the need for poetry appreciation teaching materials for students of the Indonesian Language and Literature Study Program, Kuningan University is as follows. This is as follows. (1) Needs: In-depth theory, assignment instructions, examples of performances, contextual approaches, expert content; (2) Lacks: incomplete theory, no examples of poetry performances, no assignments; (3) Want: characteristics of teaching materials, poetry analysis, pictures, video examples of poetry performance practices.
\end{abstract}

Keywords: Needs Analysis; Teaching Materials; Poetry Appreciation

\section{Introduction}

One of the achievements of learning specific skills in the Indonesian National Qualifications Framework (KKNI) for undergraduate students of the Indonesian Language and Literature Study Program is being able to appreciate, express, and create Indonesian literary works orally and in writing (APROBSI, 2014: 10). Appreciate, express, and create means to enjoy, enjoy, express, react and create literary works, be it poetry, prose fiction, and drama. These learning outcomes are structured so that graduates have skills in the field of literature and apply them in literature learning. With good literary skills, it is hoped that graduates who love, appreciate, and are to able teach and develop Indonesian literary works. 
The results of a preliminary study conducted in August 2019 regarding the implementation of literature appreciation learning at the Department of Education Indonesian Language and Literature, Kuningan University, it is known that literary appreciation learning activities at Kuningan University are divided into six subjects, namely poetry anatomy, poetry appreciation, prose anatomy fiction, appreciation of prose fiction, anatomy of drama and appreciation of drama. Poetry anatomy, prose fiction anatomy, and drama anatomy courses deals with the study of poetry, prose fiction, and drama.

The studies conducted were in the form of structural, psychological, and sociological studies. Meanwhile, poetry appreciation, prose fiction appreciation and drama appreciation courses are related to creative activities. In the poetry appreciation course, the creative activities carried out are reading, reciting, musicalizing, dramatizing, and writing poetry. In the fiction prose appreciation course, the creative activities carried out are writing prose fiction, reading prose fiction, and dramatizing fictional prose. In the drama appreciation course, creative activities are carried out, namely writing drama scripts and performing plays. In the appreciation course (poetry, prose fiction, drama), the form of examination is practice and is held annually. Based on the results of the analysis of the scores of student courses, it was found that the average value of the poetry appreciation course was below the value of the drama appreciation and prose fiction appreciation courses. The results of the analysis of the value of literary appreciation showed that the value of the poetry appreciation course was below the average value of the appreciation of fiction and drama prose. This is in line with the results of the interview. The results of the interview stated that the most difficult subject in literary appreciation was the poetry appreciation course.

The reasons stated why poetry appreciation is difficult include the following. First, appreciation of poetry is difficult due to the relatively different character of the language of poetry from prose. Second, poetry appreciation is said to be difficult because the process and stages are complex. To appreciate poetry, students must go through a series of interrelated processes, such as reading, analyzing, and producing in other forms. From the results of the interviews, it was understood that the difficulties of students in appreciating poetry (reading poetry) included adjusting the tempo, determining the tone, pressure, rhythm and intonation, as well as training vocals and self-confidence. The third factor that makes appreciation difficult is due to the many learning outcomes that students must master in the poetry appreciation course. This can be seen from the results of the analysis of the semester learning plan (RPS). The learning outcomes included reading beautifully, reciting, musicalizing, dramatizing, and writing poetry.

In line with the difficulties experienced by students, Kangley (1937: 222-224) stated that the problem of poetry appreciation was caused by two things, namely the selection of poetry and its presentation. The two things are closely related and cannot be separated. Each poem has its own uniqueness, and because it is unique, it requires a separate technique for its presentation. Apart from Kangley, Bailey (1977: 512-515) states that poetry as one of the literary genres whose language is condensed is relatively more difficult to understand than other genres such as prose and drama. Noor (2018: 18) say that because of the unique language, poetry is sometimes a little difficult to understand. Poetry cannot be read casually like reading prose or news. Reading poetry needs seriousness, solemnity and sacrifice, with a continuous process of practice. Therefore, in trying to understand poetry, an in-depth analysis of its elements is required. Poetry elements must be considered to find a complete context. In understanding poetry, repeated reading can be an introduction to understanding. If in prose the meaning can be understood and guessed at, in poetry it cannot be done. The compression of words in poetry makes the meaning more difficult to find in its entirety. Poetry always 
contains two meanings, surface meaning and hidden meaning. Meanwhile, the complexity of the process in appreciating poetry was also revealed by Daswati (2012: 1-2) who stated that to be able to read poetry well, the first thing that needs to be done is to understand the meaning of poetry. Daswati's opinion is complemented by Surastina (2016:23) which states that poetry reading skills are also related to pronunciation skills, emphasizing, and processing intonation. Apart from the process and stages, appreciation is also related to attitudes, knowledge and skills. Prayitno (2013: 2) gives an opinion about the relationship between attitudes, knowledge and skills in poetry appreciation.

Appreciating poetry (reading aloud, writing, reciting, musicalizing, dramatizing) is closely related to certain skills such as vocal skills, musical skills, writing skills, and other skills. Poetry writing skills, for example, are closely related to training to sharpen feelings, reasoning and imagination, as well as sensitivity to society, culture and the environment. From the above opinion, it can be concluded that the process of appreciating poetry goes through various stages. The first stage is reading repeatedly to understand the contents of the poem. The second stage is analyzing poetry as a basic asset for making the concept of poetry appreciation. The third stage is creating in other forms in accordance with the concepts that have been made. This stage cannot be overlooked because it will affect the results of the appreciation. The process of poetry appreciation also involves three taxonomic domains, namely attitudes, knowledge, and skills. These three domains are interrelated and have an important role in creating a complete appreciation process. The incompleteness of the taxonomic domain will hamper the process of appreciating poetry.

Until now, these difficulties have not been resolved. It is based on data from interviews conducted on August 23, 2019. Based on the results of interviews with students and lecturers, it is known that the teaching materials used in poetry appreciation are books and teaching materials from the internet. The books used are entitled Poetry Theory and Appreciation, Poetry Study, and the Poetry Appreciation dictate. Sources from the internet are the basic concepts of appreciation, poetry analysis, and reading poetry. The results of the analysis of the RPS show that the books used to support learning are Poetry Appreciation Guidance, Poetry and Teaching Methodology, Poetry Theory and Appreciation. The material provided in the poetry appreciation course includes structural and semiotic poetry analysis, basic concepts of appreciation, understanding of poetry reading, understanding of recitation, understanding of musicalization, understanding of dramatization, and understanding of writing poetry. Examples taken from the internet, such as video reading W.S. Rendra and the musicalization of Ari Reda's poetry. If we compare the learning outcomes with the teaching materials used, it is found that the material is incomplete. The material provided is about the concept of poetry appreciation, definition, goals, and benefits of poetry appreciation, the appreciation process, the stages of appreciation, approaches in appreciating poetry, reading poetry and discussions about poetry, writing poetry and discussions on writing poetry, learning poetry appreciation and assessment. learning outcomes, practice reading and writing poetry.

In fact, if you look at the learning outcomes, the materials needed are poetry reading, recitation, musicalization, dramatization, and writing poetry. The material contains definitions, characteristics and limitations, steps, examples, and assessments. Apart from the incomplete material, there was a mismatch between the learning outcomes and the source books used. Learning outcomes are able to hold reading performances, recitations, dramatizations, and poetry musicals. Meanwhile, the source book used contains material on how to understand poetry, Indonesian poets, various kinds of poetry, examples of poetry analysis, and the history of poets. 
There is a mismatch between learning outcomes and the books used. The material in the source book emphasizes how to analyze poetry, not doing creative activities to hold reading performances, recitations, musicals, and poetry dramatizations. If examined more deeply, books used as references are more suitable for the course of poetry anatomy. Whereas the results of preliminary studies show that when appreciating poetry (reading poetry) students mostly have difficulty determining the tempo, pressure, tone, rhythm, intonation, and training self-confidence. Puspita, Andayani, Waluyo, and Rohmadi also expressed the teaching materials for poetry appreciation (2017: 622-623). The results of their research stated that the results of the survey of poetry appreciation textbooks used by universities in Central Java were still minimal. The books used in six universities in Central Java are the Study and Appreciation of Poetry, Study of Poetry, getting to Know Poetry, Stylistics, and Musicalisation Discourses.

The things above show that learning poetry appreciation at the Kuningan University requires complete and contextual teaching materials. Johnson (2010: 67) states the reasons for the importance of a contextual approach used in teaching materials as follows. The contextual approach is an educational process that aims to help students see meaning in the academic material they learn by connecting academic subjects with contexts in their daily lives. This context encompasses the context of personal, social and cultural circumstances. The context that is presented will make students understand and give meaning to what they are learning. Based on the background of the problems above, this study aims to reveal the need for poetry appreciation teaching materials. This need must be addressed, so that the resulting poetry appreciation teaching materials are complete and contextual.

\section{Method}

The method used in this research is qualitative research methods. The data collection techniques used were interviews, observation, and literature study. The primary data of this research are the results of interviews. Meanwhile, secondary data are in the form of observations and literature studies. Data from observations and literature studies are used to check the validity and reliability of interview data, hereinafter referred to as data triangulation. After the data is obtained, the next step is processed. Creswell (2012: 212) states that qualitative data is divided into 5 categories, namely observation, interviews, questionnaire, document and audiovisual materials. The qualitative data obtained in this study were used to answer the problem formulation as well as become the basis for developing the design of teaching materials. After the data is obtained, then the analysis is carried out through several stages, namely data collection, data reduction, data presentation, and conclusion.

\section{Result and Discussion}

\subsection{Teaching Material Conditions}

The teaching material conditions section is the result of a preliminary study. The matters that will be discussed in this section include the identification results of course learning outcomes, instructional analysis, student profiles, students' poetry appreciation abilities, and the availability of poetry appreciation teaching materials at the Kuningan University. 


\subsubsection{Learning Objective Identification}

Learning objectives identification is the stage of knowing and determining general competency that will be mastered by students after participating in the learning process. Based on the results of the identification of learning objectives listed in the Department of Education Indonesian Language and Literature Curriculum, FKIP Uniku, it is known that Graduate Learning Outcomes (CPL-Prodi) include attitudes, knowledge and skills. CPL-department is in the realm of attitude, namely being devoted to God Almighty and showing a religious attitude, contributing to improving the quality of life in society, nation, state, and progress of change based on Pancasila, and respecting the diversity of cultures, views, religions and beliefs, as well as opinions, or someone else's original finding. In the realm of knowledge, namely mastering the theoretical concept of developing language and literature learning.

In the realm of general skills, namely being able to apply logical, critical, systematic, and innovative thinking in the context of developing or implementing science and technology that pays attention to and applies the humanities values in the field of Indonesian language and literature education. Whereas in the realm of special skills, namely being able to appreciate, express, create Indonesian literary works orally and in writing. The CPL-department is then further elaborated through Course Learning Outcomes (CPMK) and Subject Learning Outcomes (Sub-CPMK).

CPMK in the department of education Indonesian Language and Literature, Kuningan University are (1) students are able to explain the concept of poetry appreciation; (2) students are able to explain the types of poetry appreciation; (3) students are able to distinguish the types of poetry appreciation; (4) students are able to master the concept of reading poetry with proper pronunciation, tone, intonation, and tempo and apply them; (5) students are able to master the concept of poetry recitation with proper pronunciation, tone, intonation, and tempo and apply it; (6) students are able to master the concept of poetry Musicalisation by referring to the contents of the poetry and applying it; (7) students are able to master the concept of poetry dramatization by referring to the poetry content and applying it; (8) students are able to master the concept of writing poetry by referring to their experiences.

The CPMK sub-class for the Poetry Appreciation course, namely: (1) students are able to explain the meaning of poetry appreciation, types of poetry appreciation activities, and different types of poetry appreciation; (2) students are able to explain the meaning and steps of creative poetry reading activities; (3) students are able to demonstrate basic exercises to read poetry; (4) students are able to explain poetry reading assessment; (5) students are able to read poetry with correct pronunciation, intonation and rhythm; (6) students are able to explain the meaning and steps of reciting poetry; (7) students are able to explain the practice and assessment of poetry recitation; (8) students are able to explain the meaning and types of musical poetry; (9) students are able to identify the steps of creative poetry musical activities; (10) students are able to explain the practice and assessment of poetry Musicalisation; (11) students are able to explain the meaning and dramatization steps of poetry; (12) students are able to explain the dramatization of poetry exercises and assessments; (13) students are able to explain the meaning and steps of writing poetry; (14) students are able to explain the practice and assessment of writing poetry.

Based on the CPL of the department, CPMK, and Sub-CPMK, it can be concluded that the learning achievements of the poetry appreciation course are mastery of the concept of poetry appreciation, mastery of the concept of creative reading, recitation, Musicalisation, dramatization, and writing poetry, mastery of reading skills, recitation, Musicalisation, dramatization., and wrote poetry. Related to this research, the learning outcomes will be 
focused on mastering the concept of poetry appreciation, mastery of the concept of reading poetry, and mastery of poetry reading skills.

\subsubsection{Student Profile}

Student profile analysis is important to do to determine the characteristics of students who will use poetry appreciation teaching materials. This is important because the teaching materials to be used must be in accordance with the characteristics of the user. This is in accordance with Vygotsky's opinion which states that in order for learning to be meaningful, it needs to be designed and developed based on the condition of students as learning subjects and the socio-cultural community where students live (Moll, 1994).

Analysis of student profiles includes age and social background of students. There are 60 students of the Department Indonesian Language and Literature FKIP Kuningan University in semester 2. A total of 19 students are male, and 41 students are female. Their age range is 1921 years. Cognitively, the age range 19-21 years according to Piaget is in the formal operational stage. This means that at that age, students are to able think abstractly, work effectively and systematically, analyze in combination, think proportionally, and draw generalizations / conclusions. When viewed based on language development, at that stage students are to able use words more effectively, understand metaphors and adult literature, and improve writing skills. Judging from the social background, the average student comes from rural areas spread over four (4) districts namely Kuningan, Majalengka, and Cirebon and Berebes.

The average occupation of their parents is farmers $(60 \%)$, traders $(30 \%)$, and employees $(10 \%)$. Based on the research results (Subiyanto, 2012), it is known that the learning achievement of students in rural areas is lower than the learning achievement of students in urban areas. The low learning achievement of students in the village environment is influenced by low learning motivation, lack of family support capacity, and limited teaching facilities and materials.

\subsubsection{Student Ability of Poetry Appreciations}

Based on the results of the initial test of poetry appreciation (reading poetry) on 10 (ten) Indonesian Language and Literature Education students, it is known that as many as $10 \%$ of students get very good scores, $15 \%$ of students get good scores, and $20 \%$ of students get sufficient grades, and $55 \%$ of students have poor grades. That means, more than half of the students who took the initial test regarding poetry appreciation (reading poetry) had poor skills. Based on the results of the interview, the problem of the low ability to appreciate poetry is caused by factors of knowledge, technical factors, and appreciation factors.

The knowledge factor is related to the ability to understand the contents of the poetry. In appreciating poetry (reading poetry), understanding the contents of the poetry is very important so that the message in the poetry can be accepted by the listener. The second problem faced is technical problems in reading poetry. The technical problems are related to the pause, emphasis, and timing of the poetry reading. The third problem relates to psychology and self-confidence in reading poetry. Self-confidence is so important in reading poetry.

Without good confidence, it is impossible to read a good poem. from the results of the interview, it was known that students had knowledge in the field of poetry appreciation (reading poetry) related to clarity of pronunciation / articulation, vocal strength, and accuracy of intonation and emphasis. Knowledge of vowels, pronunciation / articulation, intonation, and emphasis was obtained by students when they were in Senior High School (SMA).

\subsubsection{Availability of Poetry Appreciation Teaching Materials}

Based on the results of interviews with students and lecturers, it is known that the teaching materials used in poetry appreciation are books and teaching materials from the internet. The 
books used are entitled Poetry Theory and Appreciation, Poetry Study, and the Poetry Appreciation dictate. Sources from the internet are the basic concepts of appreciation, poetry analysis, and reading poetry. The results of the analysis of the RPS show that the books used to support learning are Poetry Appreciation Guidance, Poetry and Teaching Methodology, Poetry Theory and Appreciation.

The material provided in the poetry appreciation course includes structural and semiotic poetry analysis, basic concepts of appreciation, understanding of poetry reading, understanding of recitation, understanding of Musicalisation, understanding of dramatization, and understanding of writing poetry. Examples taken from the internet, such as video reading W.S. Rendra and the Musicalisation of Ari Reda's poetry. The material provided is about the concept of poetry appreciation, definition, goals, and benefits of poetry appreciation, the appreciation process, the stages of appreciation, approaches in appreciating poetry, reading poetry and discussions about poetry, writing poetry and discussions on writing poetry, learning poetry appreciation and assessment. learning outcomes, practice reading and writing poetry.

If you look at learning outcomes, there is a lack of material completeness. The materials needed are poetry reading, recitation, Musicalisation, dramatization, and writing poetry. The material contains definitions, characteristics and limitations, steps, examples, and assessments. Especially for reading poetry, there are deficiencies in the steps and basic exercises for reading poetry. In addition, there was a mismatch between the learning outcomes and the source books used. Learning outcomes are to able hold reading performances, recitations, dramatizations, and poetry musicals. Meanwhile, the source book used contains material on how to understand poetry, Indonesian poets, various kinds of poetry, examples of poetry analysis, and the history of poets.

There is a mismatch between learning outcomes and the books used. The material in the source book emphasizes how to analyze poetry, not doing creative activities to hold reading performances, recitations, musicals, and poetry dramatizations. If examined more deeply, books used as references are more suitable for the course of poetry anatomy. Whereas the results of preliminary studies show that when appreciating poetry (reading poetry) students mostly have difficulty determining the tempo, pressure, tone, rhythm, intonation, and training self-confidence.

\subsubsection{The Needs of Teaching Materials}

Based on the analyzed data, there is the fact that there are still aspects of need, deficiency, and desire in learning poetry appreciation. The teaching materials used as references by students on average only use two books, namely Appreciation of the Poetry by Herman J. Waluyo and First Steps to Appreciation of Indonesian Poetry by Aan Sugiantomas, which in terms of content leads to poetry analysis and basic theory of poetry itself. This is of concern to researchers and is an aspect of the need for literacy teaching materials to see how teaching materials are more complete than those used by students. From the statements of students and lecturers who were participants, the most prominent aspects of shortcomings and the most wanted to be asked for as a desire for teaching materials were theory, steps, to practice of poetry appreciation consisting of poetry reading, poetry Musicalisation, and poetry dramatization.

This theory will make the teaching materials compiled by researchers will have distinctive characteristics and are more complete than existing books. Another aspect that supports the teaching material is the graphic aspect or appearance of the teaching material. 
The need for poetry appreciation teaching materials on the display was asked by student respondents to attract and contain explanatory images, which means that the teaching materials are arranged interactively and spoil the eyes of the readers. The appearance in teaching materials starts from a cover that attracts readers with the latest designs. In appearance the text is more neat's but varied in terms of layout. Related to the content of the poetry appreciation teaching material answered by the respondent, in addition to the material that has been explained in the previous paragraph.

The content of teaching materials must also contain elements of contextually, which is an environment-based learning that makes students appreciate poetry to take advantage of and appreciate the surrounding environment as well as being treated to what is from the environment. Still discussing the content of teaching materials. Expert opinion, expert experience, and many related to experts in Kuningan regency regarding poetry appreciation are aspects they want in teaching materials. One participant answered that the experts could provide them with motivation and become a reference in poetry appreciation until they could join the competition as a place to hone their skills in poetry appreciation. To illustrate the findings in the need analysis, the researcher presents the findings framework in the follow chart.

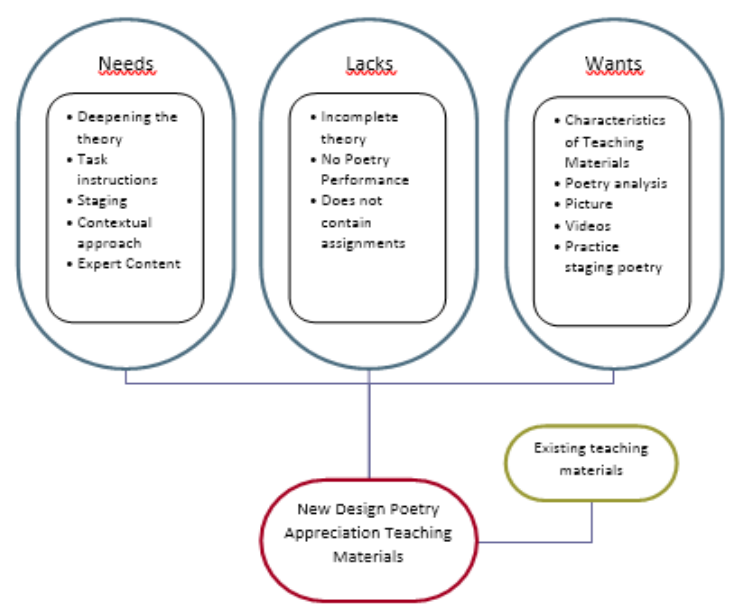

Fig 4. Data Analysis Chart

\section{Conclusion}

\subsection{Condition of Teaching Materials \\ 4.1.1 Identification of Learning Outcomes}

Learning outcomes of the poetry appreciation course are mastery of the concept of poetry appreciation, mastery of the concept of creative reading, recitation, Musicalisation, dramatization, and writing poetry, mastery of reading skills, recitation, Musicalisation, dramatization, and writing poetry. Related to this research, the learning outcomes will be focused on mastering the concept of poetry appreciation, mastery of the concept of reading poetry, and mastery of poetry reading skills. 


\subsubsection{Student Profile}

There are 60 students of the Indonesian Language and Literature Study Program FKIP Kuningan University in semester 3. A total of 19 students are male, and 41 students are female. Their age range is 19-21 years. Cognitively, the age range 19-21 years according to Piaget is in the formal operational stage.

\subsubsection{Poetry Appreciation Ability}

Based on the results of the initial test of poetry appreciation (reading poetry) on 10 (ten) Indonesian Language and Literature Education students, it is known that as many as $10 \%$ of students get very good scores, $15 \%$ of students get good scores, and $20 \%$ of students get sufficient grades, and $55 \%$ of students have poor grades. That means, more than half of the students who took the initial test regarding poetry appreciation (reading poetry) had poor skills.

\subsubsection{Availability of Teaching Materials}

Based on the results of interviews with students and lecturers, it is known that the teaching materials used in poetry appreciation are books and teaching materials from the internet. The books used are entitled Poetry Theory and Appreciation, Poetry Study, and the Poetry Appreciation dictate. Sources from the internet are the basic concepts of appreciation, poetry analysis, and reading poetry. The results of the analysis of the RPS show that the books used to support learning are Poetry Appreciation Guidance, Poetry and Teaching Methodology, Poetry Theory and Appreciation.

\subsection{Need for Teaching Materials}

From the statements of students and lecturers who were participants, the most prominent aspects of shortcomings and the most wanted to be asked for as a desire for teaching materials were theory, steps, to practice of poetry appreciation consisting of poetry reading, poetry Musicalisation, and poetry dramatization. Another aspect that supports the teaching material is the graphic aspect or appearance of the teaching material. The need for poetry appreciation teaching materials on the display was asked by student respondents to attract and contain explanatory images, which means that the teaching materials are arranged interactively and spoil the eyes of the readers. Expert opinion, expert experience, and many related to experts in Kuningan regency regarding poetry appreciation are aspects they want in teaching materials.

\section{References}

[1] APROBSI. (2014). Capaian Pembelajaran dan Standar Nasional Pendidikan Bahasa Indonesia. Jakarta: APROBSI

[2] Bailey, J. S. (1977). A Study Guide for a Course in Poetry Appreciation. Hispania, 60(3).

[3] Binol, Karim, Efendi. (2018). "Peningkatan Kemampuan Membaca Puisi Melalui Teknik Pemodelan Siswa Kelas IV SDN 05 Bunobogu”, Jurnal Kreatif Tadulako, Volume 5 (4)

[4] Charland, C. Louis. (1998). "Appreciation and Emotion: Theoretical Reflections on the Mc. Arthur Treatment Competence Study”. Kennedy Institute of Ethics Journal, 8.4 (1998).

[5] Creswell, John. W. (2012). Educational Research. New York: Upper Sadle River, NJ: Pearson.

[6] Daswati, Sri Rukun. (2012). Peningkatan Kemampuan Mengapresiasi Puisi Melalui Pendekatan Kontekstual. Cakra Olah Pikir Edukatif. 01.

[7] Eagleton, Terry. How to Read a Poem. 2007. Australia: Blackwell Publishing.

[8] Emzir dan Saifur Rohman. (2016) Teori dan Pengajaran Sastra. Jakarta: PT. Raja Grafindo Persada

[9] Gani, Erizal. (2014). Kiat Pembacaan Puisi: Teori dan Terapan. Bandung: Pustaka Reka Cipta.

[10] Johnson, Elaine B. 2010. Contextual Teaching \& Learning: Menjadikan Kegiatan BelajarMengajar Mengasyikkan dan Bermakna. Bandung: Kaifa. 
[11] Kangley, L. (1937). “An approach to poetry appreciation”. The English Journal, 26(3).

[12] Noor, Acep Zam-Zam. (2018). "Apresiasi Puisi dalam Gerakan Literasi”, FON : Jurnal Pendidikan Bahasa dan Sastra Indonesia, Volume 13 Nomor 2, 2018. DOI: https://doi.org/10.25134/fjpbsi.v13i2.1540

[13] Oktaviani Windra Puspita, Andayani Andayani, Herman J. Waluyo, Muhammad Rohmadi. (2017). "Kondisi Buku Teks Apresiasi Puisi di Perguruan Tinggi". Proceeding Education and Language International Conference, Vol. 1 (1) h. 622-623.

[14] Richards, Jack C. (2002). Curriculum Development in Language Teaching. United Kingdom: Cambridge University Press.

[15] Surastina, S. (2016). Students Errors in Reading Indonesian Poetry Aku (I) in Terms of Articulation and StressingIntonation. International Journal of Active Learning, 1(1). 